This is a draft chapter. The final version is available in Moscati, M, Roberts, M and Palmer, M, (eds.), Comparative Dispute Resolution Handbook. Cheltenham: Elgar Publishing, pp. 519-531. (Research handbooks in comparative law) published in 2020. https://doi.org/10.4337/9781786433039.00047

The material cannot be used for any other purpose without further permission of the publisher, and is for private use only This version downloaded from SOAS Research Online: http://eprints.soas.ac.uk/30394

\title{
36. Shifts in Dispute Resolution Processes of West African States
}

Emilia Onyema

\section{INTRODUCTION}

This chapter explores the shifts in the dispute resolution processes (DRPs) of West African states, from indigenous mechanisms of dispute resolution to contemporary litigation and modern alternative dispute resolution (ADR) mechanisms. It argues that the traditional forms of dispute processing that operated in the pre-colonial communities of West African states were subjugated to litigation during the colonial and post-colonial periods; but there is now a resurgence of private forms of dispute processing in the form of ADR processes. In recognition of this shift, all DRPs need to be fully integrated into the formal legal systems of these states to provide a coherent, pluralist DRP system. The chapter starts with a brief description of West African states and some of the factors that have influenced the shifts in their DRPs. It then discusses some forms of traditional DRPs prevalent in the pre-colonial period, and examines some of the reasons behind the ascendancy of litigation as the DRP of choice in the colonial and post-colonial eras in these states. It finally explores whether customary and modern ADR processes should be fully integrated into the DRP systems of these states to create a coherent, pluralist DRP regime.

\section{WEST AFRICAN STATES AND THE INFLUENCES ON THE SHIFTS IN THEIR DISPUTE RESOLUTION PROCESSES}

The West African geographical area is made up of 17 independent states. ${ }^{1}$ Fifteen of these states are members of the Economic Community of West African States (ECOWAS) ${ }^{2}$ and nine are also members of the Organisation pour L'Harmonisation en Afrique de Droit des Affaires (OHADA). ${ }^{3}$ There are two major non-indigenous or foreign 'influences' on the evolution of the DRPs of West African states: colonialism, which brought with it foreign laws, litigation, state courts, foreign languages and legal systems; and the foreign religions of Islam and Christianity. ${ }^{4}$

\footnotetext{
${ }^{1}$ These states are Benin, Burkina Faso, Cape Verde, Gambia, Ghana, Guinea, Guinea Bissau, Ivory Coast, Liberia, Mali, Mauritania, Niger, Nigeria, Sao Tome \& Principe, Senegal, Sierra Leone and Togo. Some sources, such as the United Nations, list 18 states in West Africa, with the inclusion of the island state of Saint Helena, which is a British Overseas Territory. Saint Helena is not included in this chapter. Mauritania may also be listed as part of North Africa.

${ }^{2}$ ECOWAS was established by the Treaty of Lagos of 28 May 1975. Mauritania and Sao Tome \& Principe are not members of ECOWAS or OHADA. For more information on ECOWAS, see www.ecowas.int/aboutecowas/basic-information (last accessed 27 August 2020); Jaye, Dauda and Amadi (2011); and Ukaigwe (2016). ${ }^{3}$ OHADA is a treaty-based organization (Treaty made at Port Louis of 17 October 1993, revised on 17 October 2008 in Quebec). Eight West African states - Benin, Burkina Faso, Cote d'Ivoire, Guinea, Guinea Bissau, Mali, Niger, Senegal and Togo (former French colonies) - and Guinea Bissau (Portuguese colony) are members of OHADA. All these states operate the civil law legal system. For more details, see www.ohada.org/index.php/en (last accessed 27 August 2020).

${ }^{4}$ These are in addition to globalization, which is evidenced through regional integration and their participation in international trade and investment and their DRPs.
} 


\subsection{Colonization, Language and Legal System}

All 17 West African states were colonized at some point in their history by one or more foreign (predominantly European) countries. ${ }^{5}$ Some of these states also maintain a multiplicity of languages, with the official language being directly linked to their former (European) colonialist country. ${ }^{6}$ These foreign official languages are English (Gambia, Ghana, Liberia, Nigeria and Sierra Leone); French (Benin, Cote d'Ivoire, Guinea, Mali, Niger, Senegal and Togo); Portuguese (Cape Verde, Guinea Bissau and Sao Tome and Principe); and Arabic (Mauritania - formerly French). The state-sponsored DRP of litigation is conducted in these official languages. ${ }^{7}$

French remains the predominantly used language in West Africa as the official language ${ }^{8}$ of eight of the 17 states. ${ }^{9}$ The use of such languages in the courts, in itself, would not pose a difficulty if the vast majority of citizens of these states understood them. However, each of these West African states has very high illiteracy rates. According to the United Nations Educational, Scientific and Cultural Organisation, literacy rates are below 50 per cent in states such as Burkina Faso, Gambia, Guinea Bissau, Mali, Niger and Senegal. ${ }^{10}$ Litigation before national courts thus has the propensity to exclude the vast majority of their populations from direct participation. ${ }^{11}$ Such exclusion disempowers and alienates litigants from this formal DRP. ${ }^{12}$ In contrast to litigation, traditional DRPs were conducted in the indigenous languages of the disputants, assuring their understanding and full participation.

Colonization also led to the transplantation of the legal systems (civil and common law) of the colonialist country into each West African state, as reflected in Table 36.1.

Table 36.1 Legal Systems of West African States

\begin{tabular}{|l|l|l|l|l|}
\hline No & State & Colonizer & Independence date & $\begin{array}{l}\text { Received legal } \\
\text { systems }\end{array}$ \\
\hline 1 & Benin Republic & France & 1 August 1960 & Civil law \\
\hline 2 & Burkina Faso & France & 5 August 1960 & Civil law \\
\hline 3 & Cape Verde & Portugal & 5 July 1975 & Civil law \\
\hline 4 & Cote d'Ivoire & France & 7 August 1960 & Civil law \\
\hline 5 & Gambia & Britain & 18 February 1965 & Common law \\
\hline
\end{tabular}

\footnotetext{
${ }^{5}$ West African states obtained independence from various colonizers between 1847 (Liberia) and 1975 (the Portuguese colonies of Cape Verde and Sao Tome \& Principe).

${ }^{6}$ The phrase 'official language' refers to one or more languages given special legal status in a particular jurisdiction and used within its government, courts, schools and so on, and for all official or formal transactions. Such languages may differ from the language(s) used by the citizens of the country in their daily interactions. ${ }^{7}$ With the exception of some customary courts. Also, all formal laws are written and published in the official language.

${ }^{8}$ This is unlike in East Africa, where Swahili and Kwa-Swahili are widely spoken and also used in formal transactions.

${ }^{9}$ French was previously the official language and remains widely spoken in Mauritania.

${ }^{10}$ For more information, see www.unesco.org/new/en/dakar/education/literacy/ (last accessed 15 August 2017). One consequence of such low literacy rates is very low scores in the Human Development Index Reports. For the 2019 rankings, see United Nations Development Programme (2019).

11 This is irrespective of the fact that litigants are usually represented by counsel.

${ }^{12}$ For example, in relation to Portuguese African states, see Santos (1984: 90 at 95-96).
} 


\begin{tabular}{|l|l|l|l|l|}
\hline 6 & Ghana & Britain & 6 March 1957 & Common law \\
\hline 7 & Guinea & France & 2 October 1958 & Civil law \\
\hline 8 & Guinea Bissau & Portugal & 24 September 1973 & Civil law \\
\hline 9 & Liberia & United States & 26 July 1847 & Common law \\
\hline 10 & Mali & France & 22 September 1960 & Civil law \\
\hline 11 & Mauritania & France & 28 November 1960 & Civil law; Islamic law \\
\hline 12 & Niger & France & 3 August 1960 & Civil law \\
\hline 13 & Nigeria & Britain & 1 October 1960 & Common law \\
\hline 14 & $\begin{array}{l}\text { Sao Tome \& } \\
\text { Principe }\end{array}$ & Portugal & 12 July 1975 & Civil law \\
\hline 15 & Senegal & France & 4 April 1960 & Civil law \\
\hline 16 & Sierra Leone & Britain & 27 April 1961 & Common law \\
\hline 17 & Togo & France & 27 April 1960 & Civil law \\
\hline
\end{tabular}

According to Nwabueze (2010), these colonial links changed the legal landscape of the precolonial communities that compose these states. For example, the pre-colonial legal systems were rights based and traditional, and had predominantly unwritten laws, while the DRPs focused on maintaining filial and community cohesion. ${ }^{13}$ The colonialists, however, introduced a rules-based, formalized legal system with written laws, and their DRP focused on the individual rather than the community. Colonialism led to a shift from the dominance of customary DRPs to the dominance of litigation supported by the colonial home government/state. Post colonialism, the newly independent West African states did not formally revert to their pre-colonial DRPs, but retained litigation as the primary DRP. This was further strengthened by their constitutional democracies.

\section{$2.2 \quad$ Received Religions}

The second major import, which also influenced the shift in DRPs in these states, was religion - both Islam and Christianity. ${ }^{14}$ Prior to the reception of Islam and Christianity (in their various iterations) in these states, traditional African religions held sway. ${ }^{15}$ Today, either Islam ${ }^{16}$ or Christianity ${ }^{17}$ predominates in each state, with only a minority of West Africans still practising their traditional religions. ${ }^{18}$ However, acceptance of these foreign religions has

\footnotetext{
${ }^{13}$ For example, Ajayi and Buhari (2014: 155). For the same goal in conflict resolution in Ethiopia, see Tafese (2016: 23).

${ }^{14}$ For example, on Christianity, see Ross (1955: 161-69). On Islam and Christianity, see Mazrui (1985: 817-39) and Oba (1997: 23 at 28-29).

${ }^{15}$ For example, Oba (2008: 139-58).

16 The following states are said to have 50 per cent or more of their population as practising Islam: Burkina Faso (60.5 per cent); Gambia (95.5 per cent); Guinea (84.2 per cent); Mali (95 per cent); Mauritania (100 per cent); Niger (98.3 per cent); Nigeria (50 per cent); Senegal (95.9 per cent) and Sierra Leone (71.5 per cent).

17 The following states are said to have 50 per cent or more of their population as Christians: Cape Verde (89.1 per cent); Ghana (71.2 per cent); Liberia ( 85.5 per cent); and Nigeria (50 per cent).

${ }^{18} \mathrm{Oba}$ (2008: 142) lists the acceptance of these foreign religions as one of the factors threatening the recognition of traditional oath taking in Nigerian courts; and (ibid:154-57) discusses the impact of these received religions (which forbid, for example, the swearing by juju) on the traditional religions of Nigeria. See also Akanbi, Abdulraouf and Daibu (2015: 203-04).
} 
not led to the rejection of culture and customary practices. ${ }^{19}$ Traditional DRPs fall within customary practices and are still relevant in all West African states. Interestingly, some African states now recognize traditional or customary DRPs in their constitutions or laws on dispute resolution. ${ }^{20}$

\subsection{Modern Endogenous Influences}

Most West African states are richly endowed with natural resources and are producers of primary goods or raw materials for export. They are also large importers of finished or processed goods. These trades are conducted primarily with their colonialist countries and increasingly China. ${ }^{21}$ West African states are thus important participants in global trade and significant recipients of foreign direct investment (FDI). This directly implies that these states also participate in the modern international (commercial and investment) dispute resolution regimes. To support this participation, most West African states have enacted modern arbitration laws, ${ }^{22}$ and have ratified the New York Convention on the Recognition and Enforcement of Foreign Arbitral Awards $1958^{23}$ and the Convention on the Settlement of Investment Disputes between States and Nationals of Other States (ICSID Convention). ${ }^{24}$ Further, they have signed various bilateral investment treaties and maintain robust national investment laws, providing access to arbitration as their preferred DRP in resolving such international disputes. ${ }^{25}$

Thus, in each West African state, there is a matrix of sources of substantive laws and types of DRPs. These pluralist regimes include indigenous or customary laws, received (colonial) laws, national laws, regional and international laws, and DRPs such as customary DRPs, ADR processes and litigation. These pluralist regimes of laws, DRPs and legal systems continue to co-exist in these states, with litigation as the lead DRP.

\section{CUSTOMARY DISPUTE RESOLUTION PROCESSES}

Pre-colonial African communities were not immune to disagreements and disputes between individuals and other (neighbouring) communities (Poku 1998: 106). Prior to the colonial era, the peoples of West Africa dwelt in communities and kingdoms, ${ }^{26}$ but were not, as noted by

\footnotetext{
${ }^{19}$ Oba (2008: 158) notes that 'even educated Africans routinely consult traditional diviners and look for "traditional" and "spiritual" solutions to problems'.

${ }^{20}$ Ghana included customary arbitration in Part III of its ADR Act of 2010, while Kenya notably referred to traditional dispute resolution processes under Article 159 of its 2010 Constitution; on which, see Muigua (2018).

${ }^{21}$ See www.ecowas.int/doing-business-in-ecowas/import-and-export/ (last accessed 27 August 2020).

${ }^{22}$ For details, see Bosman (2013).

${ }^{23}$ Gambia, Guinea Bissau, Sierra Leone and Togo are not member states of the New York Convention: www.uncitral.org/uncitral/en/uncitral_texts/arbitration/NYConvention_status.html (last accessed 25 August 2020).

${ }^{24}$ Guinea Bissau signed the ICSID Convention in 1991 and is yet to ratify it. All the other West African states are members of the ICSID Convention: https://icsid.worldbank.org/en/Pages/about/Database-of-MemberStates.aspx (last accessed 27 August 2020).

${ }^{25}$ See Asouzu (2001: 228-33) for a critique of the linkage between access to arbitration and attraction of FDI.

${ }^{26}$ Some of these kingdoms include the Edo, Nri, Kanem-Bornu, Sokoto, Oyo (Nigeria); Ashanti (Ghana); Songhai and Mali empires.
} 
Roberts, 'centralized state organisations' (Roberts 2013: 2). Powerful kingdoms, chiefs and families controlled defined geographical areas. These were recognized as custodians and enforcers of their customs. ${ }^{27}$ They possessed the authority to enforce decisions made by duly recognized decision makers who applied customary laws accepted by the members of such communities. ${ }^{28}$

These indigenous communities had their own forms of adjudicatory and non-adjudicatory DRPs,${ }^{29}$ commonly referred to as 'customary forms of dispute resolution' (Elias 1956: 212 ff). The basic outlines of these customary processes are seen in the modern DRPs of negotiation, mediation, conciliation and arbitration (Ajayi and Buhari 2014: 149-51). Customary DRPs were prevalent in these communities before the advent of colonial rule (Nwabueze 1963: 45). Notably, Allott contests this distinction between the different processes under customary law. In his view, 'all customary settlements of disputes' other than before the courts are known as customary arbitration (Allott 1960: 125-26). One explanation for his view and that of similar commentators (eg, Matson 1953: 58) is their perception of African DRPs through European (or foreign) lenses and constructions. ${ }^{30}$ They did not seek to understand these processes from the perspective of the Africans themselves.

There are two main distinctive attributes of customary DRPs as compared to modern DRPs. ${ }^{31}$ First, the nature of the dispute affects the level of the dispute resolver. For example, family disputes (eg, divorce and child custody matters) were resolved primarily at the level of the family, kindred or village. Land and community boundary disputes were usually resolved at the level of the community; and petty crimes (eg, theft or disorderly conduct) were also resolved at the level of the kindred or community (Ajayi and Buhari 2014: 143-45). Major crimes such as destruction of property, grievous bodily harm or murder were resolved at the level of the community. ${ }^{32}$ Thus, only disputes that affected the whole community or involved communal interests were resolved at the community level. This distinction does not exist in modern DRPs.

Second, there was no formal classification of disputes by subject matter - for example, civil, commercial, family or criminal. However, the principles and rules governing the substance of each type of dispute and applicable sanctions varied. The substantive rules and laws applicable were based on accepted customs. ${ }^{33}$ There was therefore no requirement for dispute resolvers to specialize in any particular subject matter as experts. They resolved all types of disputes referred to them. They were only expected to be fair-minded, unbiased elders, knowledgeable in the customs and traditions of their particular community. There was no requirement for them to be independent of the disputants. This was primarily because the

\footnotetext{
27 This remains the same in the vast majority of African communities.

${ }^{28}$ Such authorities included the age grade associations and different cults.

${ }^{29}$ It is not practicable to describe all types of DRPs adopted in the various communities. See, for example, Woodman (1969: 128).

${ }^{30}$ Allott (1960: 125-27) was comparing arbitration under English law and customary law.

${ }^{31}$ These are aside from state sponsorship of litigation.

${ }^{32}$ For a modern account of such a conflict, see Nwolise (2005).

${ }^{33}$ Such practices and laws developed organically from the collective understanding of wrong and right of the community, over generations.
} 
communities were of close kinship. Modern DRPs require independence of the neutral and encourage subject-matter expertise by such neutrals.

In pre-colonial African communities, mediation and conciliation were used interchangeably to refer to negotiated settlement processes and were non-adjudicatory, with restorative qualities. ${ }^{34}$ The restoration of communal balance and cohesion took precedence over the vindication of the individual rights of the disputants. ${ }^{35}$ However, the prevalent DRP employed was also inquisitorial in nature. A general outline is described below.

One or more individuals from the disputing communities constituted a panel (ad hoc or standing) of dispute resolvers, before which the disputants presented their claims. Depending on the level of the dispute - whether between members of the family, kindred, village or community - the panel members might be disinterested actors or parties interested in the outcome of the dispute, as noted by Gulliver (1979).

The disputants generally spoke on their own behalf or were represented by other members of their own family or community. The representor was a senior relative, such as an older brother or uncle, especially if the disputant was female. ${ }^{36}$ There was no group of professional advocates for disputants, such as attorneys or counsel.

The disputants pleaded their cases, called and interrogated the witnesses of fact and produced evidence to support their account of the dispute or refute that of their opponent. Customary DRPs relied heavily on witnesses of fact to ascertain the accuracy of the events leading to the dispute. The witnesses were directly interrogated (or cross-examined) by the decision makers and disputants. There was also an ordered structure to such interrogations. For example, the panel of decision makers, after welcoming the parties, would request the complainant/claimant to state his or her claim and why he or she had convened the panel. The claimant would thank the panel for convening and summarize his or her claim and its basis, on either a known custom or practice or a moral principle. This would be followed by oral hearing with witnesses.

As recognized by Ajayi and Buhari, the primary task of the panel of decision makers (the panel) was to ascertain the truth and deliver justice in accordance with the customs of the particular community (2014: 142). To achieve this, the panel heard both sides, weighted the evidence adduced by each party and their witnesses, and deliberation applied any known customary law or practice to reach a decision. ${ }^{37}$ The panel gave reasons for their decision and usually explained the customary law or practice applied in reaching their decision. The panel generally tried to reach a unanimous decision and when they reconvened, their leader pronounced their decision and reasons along with the sanctions (if any) and, if relevant, the

\footnotetext{
${ }^{34}$ For comparison, see the descriptions of traditional dispute resolution processes in some East African communities (Arusha), studied by Gulliver (1963); and the Ndendeuli of Southern Tanzania (Gulliver 1971). ${ }^{35}$ Chukwuemerie (2006: 146) noted that 'cordiality was valued tremendously and as often as disputes arose they were settled with more emphasis on restoring cordiality and the general social bond. Parties' rights and liabilities were recognised in the light of (not in spite of or against) the general social good'.

${ }^{36}$ In a patriarchal community.

${ }^{37}$ For novel issues, the panel relied on their own persuasion of right and wrong in the particular circumstances of the dispute.
} 
time within which to comply with the sanctions. Decisions were made quickly and, in most cases, immediately after the hearing. ${ }^{38}$

If the losing party accepted the decision and sanction, he or she would often be expected to provide drinks ${ }^{39}$ as a form of peace offering for all present. This action signified the restoration of the fractured relationship between the disputants and the restoration of the communal balance or equilibrium. Where the losing party refused to accept the outcome, it was often possible to 'appeal' the decision to a higher authority or panel (eg, the king or chief-in-council).$^{40}$ The losing party would make that intention immediately known to the panel and there would be no reconciliatory drinks. Such notification automatically stayed the performance of the decision and any sanction. ${ }^{41}$

On appeal, there would be a full rehearing of the case and the appeal panel would make its own findings and decision. In the referral, the appeal panel would be informed of the decision made by the first panel and why the appellant disagreed with that decision. In making its decision, the appeal panel either upheld, varied or rejected the original decision and any sanctions originally imposed (Oguntomisin 2004: 10). If the appeal panel found the losing party liable and imposed any sanctions, that party would then be obligated to perform the sanctions imposed or suffer exclusion and in extreme cases compulsory expulsion from the community (Igbokwe 1997: 212). If the losing party remained displeased with the decision or sanction, he or she could comply, but not provide reconciliatory drinks.

Customary arbitration was recognized very early by the West African Court of Appeal $(\text { WACA })^{42}$ as a valid DRP. ${ }^{43}$ The existence of this process was never disputed; though in some jurisdictions, its exact elements are contested. ${ }^{44}$ Elombi, for example, notes that the Ghanaian courts applied English common law standards to determine that under Akan (in Ghana) customary law, the prior consent of the disputants was fundamental in customary arbitration, and this consent extended to the acceptance of the decision of the arbitrator as final and binding on the disputants. ${ }^{45}$ In his view, the court arrived at this decision without enquiring into the customary practices of the Akan people. ${ }^{46} \mathrm{~A}$ West African judge, who is typically educated and trained in the foreign law that is the legacy of colonialism, interpreted

\footnotetext{
${ }^{38}$ Decision making was fast because proceedings and decision were made orally.

${ }^{39}$ Usually, locally brewed alcoholic beverage.

40 The winning party may also appeal the imposed sanction.

${ }^{41}$ On the availability of different appeal structures, see Olaoba (2001) and Oguntomisin (2004).

42 The WACA was the appeal court for the British West African colonies of Nigeria, English speaking Cameroon, Ghana, Sierra Leone and Gambia. Appeals from the WACA went to the Privy Council.

${ }^{43}$ In such cases as Foli v Akese (1930) 1 WACA 1; Kweku Assampong v Kweku Amuaku (1930) 1 WACA 192; and Kwasi v Larbi (1956) 13 WACA 76.

${ }^{44}$ One example is Nigeria; on which, see Igbokwe (1997) for a discussion on the contending arguments under Nigerian law. Note recent decisions from the Nigerian courts in Achor v Adejoh (2010) 6 NWLR (Pt 1191) 537; Awonusi v Awonusi (2007) All FWLR 1642 at 1657, where the Court of Appeal held that the consent of the parties to arbitration extends to acceptance of the award; and Okoye v Obiaso (2010) 8 NWLR (Pt 1191) 145. For critiques of the interpretation of the courts of Nigerian customary arbitration, see Akanbi, Abdulraouf and Daibu (2015: 199-221).

${ }^{45}$ For example, Allott (1960: 127).

${ }^{46}$ Elombi (1993: 815-17); on Nigeria, see Idornigie (2007: 73).
} 
(and often continues to interpret) customary laws and processes through a 'foreign' lens. ${ }^{47}$ This is a good example of the negative legacy of the colonial administration on the interpretation of elements of customary DRPs.

As already noted, West African states have modern arbitration laws primarily for use in commercial disputes. ${ }^{48}$ The arbitration laws of some of these states reflect the evolution of modern arbitration laws and rules, particularly the United Nations Commission on International Trade Law (UNCITRAL) Model Law on International Commercial Arbitration 1985 (revised in 2006) and the UNCITRAL Arbitration Rules of 1976 (revised in 2010). ${ }^{49}$ In addition, there has generally been a rise in the number of arbitration centres and institutions operating in Africa, ${ }^{50}$ and the courts in Africa are beginning to appreciate that their support for the international arbitration process is indispensable to its continued growth, acceptance and development. ${ }^{51}$ Finally, there is now a recognized African arbitration community which continues to engage with various stakeholders on the development of arbitration in Africa. ${ }^{52}$

\section{ASCENDANCY OF LITIGATION AS THE DISPUTE RESOLUTION PROCESS OF CHOICE}

In pre-colonial African communities, there were no formal centralized public courts as creations of the state. Each community had its own DRPs which it constructed and applied, and ensured compliance through its own institutions. Members of these communities accepted and legitimized these processes and institutions. As noted above, colonialism introduced formal (and foreign) laws and legal systems in these states, including formal courts that resolved disputes with the full support of the colonial administrations. Following political independence, these states retained their colonial structures, including court systems. The different levels of court and their jurisdictions are contained in their constitutions. ${ }^{53}$

One distinguishing feature of litigation is the deployment of the police powers ${ }^{54}$ of the state to facilitate the enforcement of its outcome. ${ }^{55}$ A second distinguishing feature is the judiciary being an arm of the state itself. As a process, litigation and the court system are impersonal,

\footnotetext{
${ }^{47}$ See Chukwuemerie (2006: 152-56) on the transition of the judicial officers from European colonialists to local Africans educated in the laws and mores of the Europeans in Europe, leading to the continuation of the colonial judicial machinery, with particular reference to arbitration.

${ }^{48}$ For a brief history of the arbitration laws in francophone African countries, see Amoussou-Guenou (1998: 62$66)$.

${ }^{49}$ See Bosman (2013), and in particular Part V on OHADA and its member states and Part II on West Africa and its constituent states.

${ }^{50}$ There are no known arbitration centres or institutions in Cape Verde, Gambia, Guinea Bissau, Mauritania, Sao Tome \& Principe and Sierra Leone. See Onyema (2020).

${ }^{51}$ For detailed analysis of the attitudes of African national courts towards arbitration, see Onyema (2018).

${ }^{52}$ See the SOAS Arbitration in Africa conferences organized by the author, www.researcharbitrationafrica.com/ (last accessed 27 August 2020). See also the African Arbitration Association, www.africanarbitrationassociation.org/ (last accessed 27 August 2020).

${ }^{53}$ For example, Part VII of the 1999 Constitution of Nigeria (as amended); Chapter 11 of the 1992 Constitution of Ghana; Chapter VIII of the 1996 Constitution of Gambia (as amended); and Title VI of the 1990 Constitution of Benin Republic.

${ }^{54}$ On the police powers of the state, see Hayward (1984: 19-39).

${ }^{55}$ Roberts (2013: 105) noted that traditional dispute resolvers did not enjoy the police powers of the state for the enforcement of their decisions.
} 
independent and formal institutions, and the judges may not be known to the disputants. This is in contrast to the decision makers under customary DRPs, who resided in the same community and were well known to the disputants. Also, the formality of the court system and the use of professional intermediaries (attorneys) differ from the simple procedure under customary DRPs. These features led to the entrenchment of litigation as the DRP of choice in these states from the colonial period to the present time.

It is arguable that these states have a vested interest in the promotion of litigation and the support industry of legal service providers reliant on its continuing existence. This industry includes courts and their machinery, police and prison services, universities and law schools, law graduates, law firms and attorneys and other legal service providers. Over the years, this industry has grown and become entrenched in these states (and globally), and contributes to the social, economic and human development of these states. Thus, at present, litigation remains the primary (though not necessarily the preferred) method of dispute resolution in West African states.

\section{REVERSION TO ADR PROCESSES}

Litigation with all the support of the state nevertheless soon suffered from the effects of its own success. The courts started registering too many cases, leading to severe backlogs which increased yearly. This was not matched with increased funding of the judiciary by the state. The incomes of these states dwindled with fluctuating commodity prices. ${ }^{56}$ In addition, internal conflicts and civil disturbances meant that resources were deployed to other sectors of the state. The number of judges for the burgeoning workload decreased and became grossly inadequate. ${ }^{57}$ These factors led to severe delays in justice delivery across West Africa, with a negative impact on access to justice indicators for these states. ${ }^{58}$ The current condition of most judiciaries across West Africa is one of an inadequate number of judges, systemic inefficiencies in the administration of justice, severe delays in justice delivery through the courts and allegations of judicial corruption. ${ }^{59}$ This erosion of the very factors that made litigation attractive to disputants (professional dispute resolvers and efficiency) is leading to a paradigm shift towards greater recourse to modern ADR processes. ${ }^{60}$

Modern ADR processes are attractive primarily because they are faster than litigation before West African state courts. However, they are more expensive than litigation. This is because disputants pay for the administration of the ADR processes (the fees and expenses of the decision makers and the administration costs of the reference). This is unlike litigation, where the state (and its taxpayers) pay the decision makers and contribute to the cost of legal

\footnotetext{
${ }^{56}$ See, for example, information on the economic situation of African states compiled by the World Bank (2017).

57 Taking the example of Ghana in 2017-18 Annual Report, there were 383 judges of superior courts and magistrates for a population of 28.21 million.

${ }^{58}$ For example, see World Justice Project (2016). The same trend is noticeable in the 'enforcing contracts' indicator of the Ease of Doing Business Rankings of the World Bank Group (2019).

${ }^{59}$ On perceptions of corruption in the judiciaries of various African states, see Freedom House (2011).

${ }^{60}$ Examples of some of the modern ADR processes imports include early neutral evaluation, expert determination and med-arb.
} 
administration. In addition, the outcome from ADR processes is not self-enforcing. If not voluntarily performed, it can be enforced only through the courts, requiring recourse back to litigation to access the police powers of the state.

Some West African states are now exploring ways to make ADR processes more accessible to the general public through state institutions. ${ }^{61}$ This is in addition to providing courtannexed ADR services ${ }^{62}$ and the multi-door court house scheme. ${ }^{63}$ These efforts, if sustained, will lead to greater access to justice and affordable DRPs in these states. Although litigation is the primary DRP in these states, the more 'traditional' processes of negotiation, mediation, conciliation and arbitration remain in use. ${ }^{64}$ Modern versions of these DRPs are now also recognized by the state and its courts, and adopted in the resolution of various types of disputes. ${ }^{65}$ As an example of good practice, Ghana notably included provisions on customary arbitration in its Alternative Dispute Resolution Act of 2010. ${ }^{66}$ Other West African states need to emulate the example of Ghana, as this will elevate customary DRPs from secondary level DRP to primary level, which currently is occupied only by litigation and modern arbitration. Finally, West African states also need to incorporate modern ADR processes into their DRP systems and recognize the outcome from such processes as binding on the parties and enforceable by the state through summary procedures.

\section{CONCLUSION}

This chapter argues that the pre-colonial communities that constitute West African states organically devised different forms of DRPs and their own strategies for enforcing the decisions from such processes. The colonial era saw the introduction of litigation, a foreign construct and system. As compared to traditional African DRPs, litigation is a modern process sponsored by the state and remains very popular. This dominance of litigation which is plagued by delays, inadequate (human and infrastructure) resources and perceptions of corruption in the judiciary - is on the decline. It further argues that although these different DRPs continue to co-exist in the dispute resolution space of West African states, the current shift away from litigation should be welcomed, as it creates room for these states to better integrate both traditional and modern forms of DRPs into their formal legal systems. Such integration will bring coherence to the pluralist DRPs regime currently operating in these states and create a singular DRP regime, with litigation before state courts at the top of the hierarchy. This will further ensure state-backed enforcement of decisions from customary DRPs and ADR processes, which will make them more attractive to citizens and increase access to justice.

\footnotetext{
${ }^{61}$ For example, the Citizen Mediation Service of Lagos State (Nigeria) for the resolution of low-value civil disputes. For information on statistics of disputes, see http://lagosministryofjustice.org/offices/citizensmediation-centre/ (last accessed 27 August 2020).

${ }^{62}$ For example, Ghana, where the court-annexed ADR programme was institutionalized in 2005.

${ }^{63}$ Onyema (2013: 96-129).

${ }^{64}$ See the concluding comment by Oba (2011: 79).

${ }^{65}$ For example, through the adoption of arbitration or ADR laws and their recognition before the courts of West African states.

${ }^{66}$ For more details on the Ghana ADR Act 2010, see Onyema (2012: 101-24).
} 


\section{REFERENCES}

Ajayi, Theresa A. and Oluwafemi L. Buhari (2014) 'Methods of Conflict Resolution in African Traditional Society’, 8(2) An International Multidisciplinary Journal, Ethiopia 13857.

Akanbi, Muhammed M., Lukman A. Abdulraouf and Abdulrazaq A. Daibu (2015)

'Customary Arbitration in Nigeria: A Review of Extant Judicial Parameters and the Need for Paradigm Shift', 6(1) Afe Babalola University Journal of Sustainable Development, Law and Policy 199-221.

Akpan, Monday B. (1973) 'Black Imperialism: Americo-Liberian Rule over the African Peoples of Liberia, 1841-1964', 7(2) Canadian Journal of African Studies 217-36.

Allott, Antony (1960) Essays in African Law. London: Butterworth \& Co.

Amoussou-Guenou, Roland (1998) 'The Evolution of Arbitration Laws in Francophone Africa', 64(1) Arbitration 62-66.

Asouzu, Amazu A. (2001) International Commercial Arbitration and African States. Cambridge: Cambridge University Press

Attah-Poku, Agyemang (1998) African Ethnicity: History, Conflict Management, Resolution and Prevention. Lanham: University Press of America

Bosman, Lise (ed) (2013) Arbitration in Africa: A Practitioner's Guide. Alphen aan den Rijn: Wolters Kluwer.

Chukwuemerie, Andrew (2006) 'The Internationalisation of African Customary Law', 14 African Journal of International \& Comparative Law 143-75.

Dickerson, Claire Moore (ed) (2009) Unified Business Laws for Africa: Common Law Perspectives on OHADA. London: GMB Publishing.

Elias, Teslim O. (1956) The Nature of African Customary Law. Manchester: Manchester University Press.

Elombi, George (1993) 'Customary Arbitration: A Ghanaian Trend Reversed in Nigeria', 5 African Journal of International and Comparative Law 803-24.

Freedom House (2011) Selected Data on Global Democratic Governance: Countries at the Crossroads, https://freedomhouse.org/sites/default/files/2020-

02/Countries_At_The_Crossroads_Booklet_2011.pdf(last accessed 27 August 2020).

Ghana Judiciary (2017-18) Annual Report

http://judicial.gov.gh/jsfiles/annualrep20172018.pdf (last accessed 27 August 2020). 
Gulliver, Philip H. (1963) Social Control in an African Society: A Study of the Arusha, Agricultural Maasai of Northern Tanganyika. Boston: Boston University Press.

Gulliver, Philip H. (1971) Neighbours and Networks: The Idiom of Kinship in Social Action Among the Ndendeuli of Tanzania. Berkeley: University of California Press.

Hayward, Fred M. (1984) 'Political Leadership, Power and the State: Generalizations from the Case of Sierra Leone', 27(3) African Studies Review 19-39.

Idornigie, Paul O. (2007) 'Overview of ADR in Nigeria', 73(1) Arbitration 73-76.

Igbokwe, Virtus C. (1997) 'The Law and Practice of Customary Arbitration in Nigeria: Agu v Ikewibe and Applicable Law Issues', 41(2) Journal of African Law 201-14.

Jaye, Thomas, Garuba Dauda and Stella Amadi (eds) (2011) ECOWAS and the Dynamics of Conflict and Peace Building. Dakar: Codesria Publishing.

Martor, Boris, Nanette Pilkington, David S. Sellers and Sebastien Thouvenot (eds) (2007) Business Law in Africa: OHADA and the Harmonization Process. London: GMB Publishing. Second Edition.

Matson, J.N. (1953) 'The Supreme Court and the Customary Judicial Process in the Gold Coast', 21 International Comparative Law Quarterly 47-59.

Mazrui, Ali A. (1985) 'Religion and Political Cultures in Africa', 53(4) Journal of American Academy of Religion 817-39.

Muigua, Kariuki (2018) 'Traditional Dispute Resolution Mechanisms under Article 159 of the Constitution of Kenya 2010', http://kmco.co.ke/wp-content/uploads/2018/08/A-PAPERON-ADR-AND-ARTICLE-159-OF-CONSTITUTION.pdf (last accessed 25 August 2020).

Nwabueze, Ben O. (1963) The Machinery of Justice in Nigeria. Cambridge: Cambridge University Press.

Nwabueze, Ben O. (2010) Colonialism in Africa: Ancient and Modern, Vol 1 (Origins, Nature and End of Colonialism in Africa). Ibadan: Gold Press Ltd.

Nwolise, Osisioma B.C. (ed) (2005) Traditional Models of Bargaining and Conflict Resolution in Africa. Perspectives on Peace and Conflict in Africa: Essays in Honour of General (Dr.) Abdulsalami Abubakar. Ibadan: John Archers Ltd.

Oba, Abdulmumini A. (1997) 'The Legal Relevance of Religion in Nigeria', 54 Punjab University Law Journal 23-32.

Oba, Abdulmumini A. (2008) 'Juju Oaths in Customary Law Arbitration and their Legal Validity in Nigerian Courts’, 52(1) Journal of African Law 139-58. 
Oba, Abdulmumimi A. (2011) 'The Future of Customary Law in Africa. in Fenrich, J., P. Galizzi and T.E. Higgins (eds), The Future of African Customary Law. Cambridge:

Cambridge University Press.

Oguntomisin, G.O. (2004) The Processes of Peacekeeping and Peace-Making in PreColonial Nigeria. Ibadan: John Archers Ltd.

Olaoba, Olufemi B. (2001) An Introduction to African Legal Culture. Ibadan: Hope Publications.

Onyema, Emilia (2012) 'The new Ghana ADR Act 2010: A Critical Overview', 28(1) Arbitration International 101-24.

Onyema, Emilia (2013) 'The Multi-door Court House (MDC) Scheme in Nigeria: a case study of the Lagos MDC', 7(2) Apogee Journal of Business, Property \& Constitutional Law 96-129.

Onyema, Emilia (ed) (2016) The Transformation of Arbitration in Africa: The Role of Arbitral Institutions. Alphen aan den Rijn: Wolters Kluwer.

Onyema, Emilia (2017) 'The Jurisdictional Tensions between Domestic Courts and Arbitral Tribunals', in Menaker, A. (ed) International Arbitration and the Rule of Law: Contribution and Conformity. ICCA Congress Series 19. Alphen aan den Rijn: Wolters Kluwer.

Onyema, Emilia (ed) (2018) Rethinking the Role of African National Courts in Arbitration. Alphen aan den Rijn: Wolters Kluwer.

Roberts, Simon (2013) Order and Dispute: An Introduction to Legal Anthropology. New Orleans: Quid Pro Books (originally published 1979 New York: Penguin Books). Second Edition.

Roebuck, Derek (2010) 'The Myth of Modern Mediation' in Roebuck, D. (ed) Disputes and Differences: Comparisons in Law, Language and History Oxford: Holo Books.

Ross, Emory (1955) 'Impact of Christianity in Africa', 298 The Annals of the American Academy of Political and Social Science 161-69.

Santos, Boaventura de Sousa (1984) 'From Customary Law to Popular Justice', 28(1/2) Journal of African Law 90-98.

Tafese, Tasew (2016) 'Conflict Management Through African Indigenous Institutions: A Study of the Anyuaa Community', 3(1) World Journal of Social Science 22-32.

Ukaigwe, Jerry (2016) ECOWAS Law. Cham: Springer Publishing.

United Nations Development Programme (2019), Global Human Development Indicators, http://hdr.undp.org/en/countries (last accessed 27 August 2020). 
Woodman, Gordon R. (1969) 'Some Realism about Customary Law: The West African Experience’, Wisconsin Law Review 128-52.

World Bank (2017), 'Economic Growth in Africa is on the Upswing Following a Sharp Slowdown', 19 April, www.worldbank.org/en/news/press-release/2017/04/19/economicgrowth-in-africa-is-on-the-upswing-following-a-sharp-slowdown (last accessed 27 August 2020).

World Bank (2019) Ease of Doing Business Rankings, www.doingbusiness.org/rankings (last accessed 27 August 2020).

World Justice Project, Rule of Law Index Reports, https://worldjusticeproject.org/ourwork/research-and-data/wjp-rule-law-index-2020 (last accessed 27 August 2020).

Cases

Achorv Adejoh (2010) 6 NWLR (Pt 1191) 537.

Awonusi v Awonusi (2007) All FWLR 1642 at 1657.

Foli v Akese (1930) 1 WACA 1.

Kwasi v Larbi (1956) 13 WACA 76.

Kweku Assampng v Kweku Amuaku (1930) 1 WACA 192.

Okoye v Obiaso (2010) 8 NWLR (Pt 1191) 145.

Websites

www.africanarbitrationassociation.org/ (last accessed 27 August 2020).

www.ecowas.int/about-ecowas/basic-information/ (last accessed 27 August 2020).

http://judicial.gov.gh/jsfiles/annualrep20172018.pdf (last accessed 27 August 2020)

https://icsid.worldbank.org/en/Pages/about/Database-of-Member-States.aspx (last accessed 25 August 2020).

http://lagosministryofjustice.org/offices/citizens-mediation-centre/ (last accessed 27 August 2020).

www.ohada.org/index.php/en/ (last accessed 27 August 2020).

www.ohada.com/clubs-ohada/1/club-ohada-benin.html (last accessed 27August 2020).

www.researcharbitrationafrica.com/ (last accessed 25 August 2020). 
https://unctad.org/en/Pages/DIAE/World\%20Investment\%20Report/World_Investment_Repo rt.aspx (last accessed 27 August 2020).

www.unesco.org/new/en/dakar/education/literacy/ (last accessed 27 August 2020).

www.uncitral.org/uncitral/en/uncitral_texts/arbitration/NYConvention_status.html (last accessed 25 August 2020). 